\title{
Comparative Effects of Different Dietary Selenium Sources on Productive Performance, Antioxidative Properties And Immunity in Local Laying Hens Exposed to High Ambient Temperature El-Deep, M. H.; M. Shabaan; M. H. Assar; Kh. M. Attia; and M. A. M. Sayed Anim. Prod. Res. Inst., Agric. Res. Center, Ministry of Agric, Dokki, Giza, Egypt. Corresponding author: Mahmoud El-Deep; E-mail:mheldeep1980@yahoo.com
}

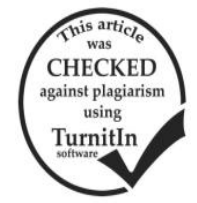

\begin{abstract}
The present study was carried out to compare the efficiency of different selenium (Se) sources [sodium selenite (SS), Se enriched yeast (Sel-Plex) and Nano-Se] on productive performance, lipid peroxidation, antioxidative status and immunity function of local chickens strain exposed to summer condition (high ambient temperature). One hundred and twenty birds, were randomly divided into 4 treatments: (1) control (basal diet without any supplementation of selenium), (2) SS (basal diet $+0.3 \mathrm{mg}$ $\mathrm{Se}$ as SS / kg diet); (3) basal diet + $0.3 \mathrm{mg}$ Nano-Se/ kg diet (Nano-Se); and (4) basal diet + $0.3 \mathrm{mg}$ organic Se/ kg diet (Sel-Plex). The experimental diets are given to birds from 30 to $42 \mathrm{wk}$ of age. Under hyperthermia, dietary $0.3 \mathrm{ppm}$ Sel-Plex or Nano-Se improved feed conversion ( $\mathrm{g}$ feed/g egg mass), egg production percentage and egg mass $(\mathrm{g} / \mathrm{d})(\mathrm{P}<0.05)$. Supplementing diets with Nano-Se increased total protein and globulin content compared with control diet. While, addition different sources of selenium significantly decreased malondialdehyde (MDA) content compared with treat (1) diet. Interestingly, under rise ambient temperature, the inclusion of $0.3 \mathrm{ppm}$ Sel-Plex or Nano-Se in the chikens diet significantly enhanced the antioxidant enzyme (GSH-Px) activity being greater than 2-folds of the controls. Chickens fed diet supplemented with Sel-Plex or Nano-Se showed about 1.5 -folds increase in seminal plasma (GSH-Px) compared with control diet. Dietary $0.3 \mathrm{ppm}$ Sel-Plex or Nano-Se had a positive significant effect on Phagocytic activity (PA) and Phagocytic index (PI) on high ambient temperature. In conclusion, dietary $0.3 \mathrm{ppm}$ organic Se or Nano-Se enhanced productive performance, antioxidative properties and immunity in chickens reared under heat stress conditions.
\end{abstract}

Keywords: hens; cockerel; Nano-Se; organic Se; antioxidative status; immunity.

\section{INTRODUCTION}

Heat stress is consider an important stressors negatively affecting in poultry industry leading to waste a lot of many each year. It has been noted that modern breeds are most sensitive to heat stress (HS) than first genotypes. Heat stress (high ambient temperature) decreases feed consumption, body weight gain, feed conversion, immune response, egg production and fertility of chickens (Siegel, 1995; Melesse et al., 2011). Stress sensibility of poultry is a main problem faces present intensive industry of poultry. It is well known that high temperature $\left(35 \pm 3^{\circ} \mathrm{C}\right)$ joined with high humidity has a harmful effect on the chickens industry by decreasing flock fertility and production. McDaniel et al., (1996) showed that fertility of broiler breeder males was highly reduced during high ambient temperatures, resulting in large annual financial losses. Several studies confirmed that heat stress significantly decreased egg production, egg mass and the index of spermatozoa quality, motility, viability and fertility; and the dead spermatozoa percentage was increased as a effect of HS (Ebeid, 2012; Kalamah, 2001). Similarly, the outcome of metabolic rates under stressors conditions, mortified levels of free radicals (ROS, reactive oxygen species) formed a formative leading to a lot of oxidative stress. Moreover, chicken and vertebrate spermatozoa show high levels of metabolic material such as (PUFA), which led them a mostly susceptible to oxidation by reactive oxygen species, specifically under stressors conditions in mammals (Aitken et al., 1989) also, domestic poultry (Surai et al., 1998a \& b; Eid et al., 2006). Production of free radicals in semen are involved in changes in spermatozoa membrane fluidity, DNA and RNA fragmentation, protein damage and, consequently, loss of spermatozoa motility and fertility (Lopes et al., 1998; Sanocka and Kurpisz, 2004). Thus, ROS production and the antioxidant enzymes must have a balance between them to established and preserve spermatozoa viability and fertility (Surai, 2002; Ebeid , 2012).
El-Deep et al., (2016) found with broiler that, ROS was prevented by natural antioxidants, which have a vital role in cells by decresing free radicals and avoiding lipid peroxidation . Surai, 2002 demonstrated that, antioxidant system has many antioxidant enzymes, like (GSH-Px), (SOD) and (CAT). Antioxidative properties was activating by the role of Se, which participation in the active site of the enzyme GSH-Px in blood, liver, seminal yolk extract and edible tissues (El-Deep et al., 2016 ; Ebeid, 2012 ; Yoon et al., 2007) antioxidant enzyme has a serves helps to control levels of lipids peroxides and ROS (El-Deep et al., 2016 ; Arthur, 2000) leading to enhancing the immunity in many species (Rayman, 2004; Ebeid et al., 2013). Several previous studies observed that addition Se was influence on growth performance, egg production, semen and quality of meat and antioxidant levels in semen, blood and egg yolk of chickens (El-Deep et al., 2016 ; Ebeid , 2012 ; Wang and $\mathrm{Xu}, 2008$ ). The Se bioavailability is associated with its forms. Inorganic informs for example sodium selenite $\left(\mathrm{Na}_{2} \mathrm{SeO}_{3} ; \mathrm{SS}\right)$, also organic forms like Selenium enriched yeast (SY) and selenomethionine ( Sel-Plex) are widely used in poultry field (Surai, 2002). Previous studies suggested that inorganic Se is more toxic than organic Se (Doucha et al., 2009). Nanotechnology holds wide promises for medication and nutrition recently in poultry field. Newly studies notice that nano-elemental like (Nano-Se) has a high bioavailability, low toxicity , best catalytic efficiency, and high ability to adsorbant compared with selenite and organic Se in chickens (El-Deep et al., 2016 ; Wang et al., 2009), rats (Jia et al., 2005 and Wang et al., 2007), sheep and goat (Shi et al., 2011a,b). However, according to our knowledge, data available on antioxidant status on semen, eggs and blood constants of hens exposed to heat-stress using Nano-Se is still limited. For that, the objective of these experimental was compared the efficiency of dissimilar Se sources (SS, SY and Nano-Se) on growth, egg production, lipids peroxidation, ant oxidative status 
and immunity function of laying hens exposed to hot climate conditions.

\section{MATERIALS AND METHODS}

Birds, the conditions of housing and environmental: A total of 30, 42-week-old hens and cockerels Inshas (Egyptian local strain) were chosen from a flock of about 120 birds $((4$ treatment $\times 3$ rep. $\times 10$ birds $(8$ hens +2 cockerels)) to obtain randomly selected from the flock of farm with similar production and weight, also spermatozoa count $\left(2.14 \pm 0.15 \times 10^{9} / \mathrm{ml}\right)$. Individual battery cages have birds, which housed in open system farm under a sixteen hour light: eight hour dark according to lighting schedule. The experiment was carried out under Egyptian conditions (from June to August) it means hot climate . In period of theses study, the daily temperature mean was ranged between 33 to $36^{\circ} \mathrm{C}$ and relative humidity average between 60 to $70 \%$ in inside the farm. The experiment was perfect according to institutional guidelines for roles of animal use.

The experimental design: All birds were provided ad libitum with water and the experimental feeds were subedited to be iso nitrogenous and iso caloric to meet the nutrients need requirements (Table 1) according to Agriculture Ministry Decree (1996). Birds were divided to the 4 experimental treatments ( 30 birds in each treatment ): (1) control (basal diet); (2) SS (basal diet + $0.3 \mathrm{mg} \mathrm{Se}$ as $\left(\mathrm{Na}_{2} \mathrm{SeO}_{3}\right)$ sodium selenite (SS) / kg diet), which produced by Sigma- Co., Japan; (3) NanoSe (basal diet $+0.3 \mathrm{mg}$ Nono-Se/ kg diet) Selenium nanoparticles 100 to $500 \mathrm{~nm}$ were provided by Eszenyi et al., (2011) ; and (4) Sel-Plex (basal diet + $0.3 \mathrm{mg}$ organic $\mathrm{Se} / \mathrm{kg}$ diet) source of selenomethionine was obtained from Alltech Inc, Tokyo . , the basal diet don't have any Se addition, also the ingredients of the feed have a low $\mathrm{Se}$, which are used to performed basal diet (calculated, $0.072 \mathrm{ppm}$ ).

Measurements: Daily egg weight and number were recorded for each hen and feed intake was recorded every week. Egg production were calculated for monthly intervals during the production period as number of egg /hen/ all period for replicates then, it calculated the meam of each treatment in whole period. Egg mass equaled egg number $\times$ mean egg weight. Feed conversion $(\mathrm{FC})=$ gram feed/ gram egg mass). At the last week of experimental quality of eggs were determined, in which 6 eggs were randomly taken from each treatment (2 eggs from each replicate). Each egg was broken to calculate egg shell, yolk and albumen percentages. Shell thickness (nn) of egg was measured by a micrometer. Yolk index and egg shape index records were calculated according to Sauter et al. (1951); according to Haugh (1937); Kotaiah and Mohapatra, (1974) and Eisen et al. (1962) haugh unit was measured. The samples of blood were collected for every hen in tubes containing heparin then divided in two parts ; first part of blood sample was centrifuged flowed that kept plasma samples at $-20^{\circ} \mathrm{C}$ for chemical analyses of total lipids, total protein, alb, globulin and AST were estimated in plasma by colorimetric methods using marketable kits, following the steps as labeled by manufactures.
Table 1. Composition and calculated chemical analysis of the basal diet.

\begin{tabular}{|c|c|}
\hline Ingredients & $\%$ \\
\hline Yellow corn & 63.23 \\
\hline Soybean meal (44\%) & 23.10 \\
\hline Limestone & 8.36 \\
\hline Corn gluten meal (62\%) & 3.15 \\
\hline Mono - Ca - P & 1.43 \\
\hline Salt $(\mathrm{NaCl})$ & 0.37 \\
\hline Vit. \& Min. Mix. ${ }^{1}$ & 0.30 \\
\hline DL-Met. 98\% & 0.06 \\
\hline Total & 100 \\
\hline \multicolumn{2}{|c|}{ Calculated chemical analysis $^{2}$ : } \\
\hline $\mathrm{CP} \quad \%$ & 17.019 \\
\hline $\mathrm{Kcal} / \mathrm{kg}$ & 2751 \\
\hline $\mathrm{CF}$ & 3.203 \\
\hline EE & 2.817 \\
\hline $\mathrm{Ca}$ & 3.404 \\
\hline Available $\mathrm{P}$ & 0.430 \\
\hline Lys. & 0.863 \\
\hline Met. & 0.387 \\
\hline Met. + Cys. & 0.676 \\
\hline $\mathrm{Na}$ & 0.162 \\
\hline ppm & 0.072 \\
\hline \multicolumn{2}{|c|}{ 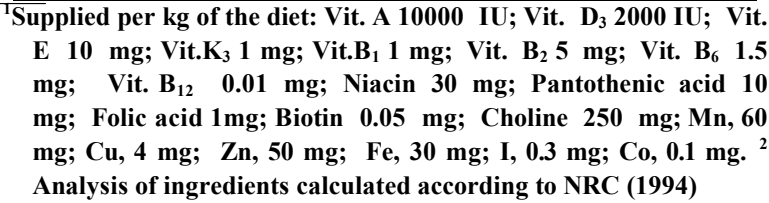 } \\
\hline
\end{tabular}

The complete blood samples kept at $4^{\circ} \mathrm{C}$ then directly determined activity of glutathioneperoxidase (GSH-Px) and phagocytosis of polymorphonuclear. Phagocytosis of polymorphonuclear cells using Candida albicans was performed. In plastic tube, the following aliquots were mixed: $100 \mu \mathrm{l}$ fetal calf serum, $100 \mu \mathrm{l}$ heat Killed Candida albicans $\left(5 \times 10^{6} / \mathrm{ml}\right)$ and $100 \mu \mathrm{l}$ blood. The tubes was mixed and incubated at $37^{\circ} \mathrm{C}$ for 30 minutes, after which it was centrifuged for $5 \mathrm{~min}$ at $1000 \mathrm{rpm}$. The supernatants were discarded leaving a droplet in to which the sediment was re-suspended. Smears were prepared from the deposit, dried in the air, fixed with methyl alcohol and stained with Giemsa stain. One hundred heterophils were examined and the number of heterophils ingesting Candida was counted and expressed as percentage.

Phagocytic activity (PA) $=$ Percentage of phagocytic cells containing yeast cells.

Number of yeast cells phagocytized

Phagocytic index $(P I)=\frac{\text { Number of phagocytic cells }}{\text { Num }}$

According to Lake and Stewart, 1978 samples of semen were collected weekly. At the last $4^{\text {th }}$ weeks of period study, The cockerels semen samples of were analysed. Semen samples were centrifuged at $2500 \mathrm{~g}$ for 20 min. At $-20 \mathrm{C}$ supernatant was stored to analysis. The volume $(\mathrm{ml})$ of the ejaculate was estimated by using a haemocytometer (Lake and Stewart, 1978). Spermatozoa motility percentages were analyzed according to (Ebeid, 2009; Słowinska et al., 2011). Spermatozoa motility according to Melrose and Laing, (1970). Viability was evaluated as the percentage of spermatozoa (Lake and Stewart, 1978). Calcium $\left(\mathrm{Ca}^{++}\right)$ in plasma of semen was estimated by the method of 
Gindler and King (1972) .Lipids peroxidation in the plasma of blood and semen were estimated the oxidative stress index thiobarbituric acid reactive substance (TBARS) in particular malondialdehyde (MDA)as described by Richard et al., (1992). The GSH$\mathrm{Px}$ in the plasma of semen were evaluated according to Paglia and Valentine, (1967) and Koracevic et al., (2001), by use kits produced by Bio-diagnostic, Egypt.

Statistical analysis: Data were subjected to ANOVA using the general linear models procedure of SPSS ${ }^{\circledR}$. Significant variance among treatment averages were compared by Duncan's new Multiple-Range Test (Duncan, 1955) at $\mathrm{P}<0.05$.

\section{RESULTS AND DISCUSSION}

Productive performance: Climatic stress, especially high ambient temperature, effects on productive performance. The effects of Se source on live body weight change $(\mathrm{g})$, feed intake $(\mathrm{g} / \mathrm{d})$ and feed conversion ratio ( $\mathrm{g}$ feed/g egg mass) are shown in Table 2. The live body weight change $(\mathrm{g})$, feed intake $(\mathrm{g} / \mathrm{d})$ were insignificantly affected by addition of all types of Se source. The effect of Se source in productive performance at the all experimental time are found in Table 2. Nano-Se Supplementation in hens diets significantly enhanced egg production percentage (\%), egg mass and feed conversion (FC) when compared with T2 (SS) or control groups, while Nano-Se and organic selenium (Sel-Plex) were insignificantly in other productive performance traits and both of them were decreased the side effects of hot climate on productive performance. The enhancement due to $\mathrm{Se}$ supplementation in diets, Se is one of an important extra issue for the key enzyme of 5-deiodinase. The importance of iodothyronine deiodinase enzymes , which was switch the pro-hormone ( inactive form) thyroxine (T4) to new active form triiodothyronine (T3). Triiodothyronine is a master hormone which controls in growth by controlling energy of body's and muscles anabolism (Arthur et al., 1999; Preter, 2000). Also, GSH-Px has in it's structure selenium. The increase ROS has led to reductions in production (Underwood and Suttle, 1999). Hens receiving $0.3 \mathrm{ppm}$ of Nano-Se significantly had the best value in both egg production percentage and egg mass by $19.60 \%, 8.56 \%$, respectively while improved feed conversion ratio by $4.05 \%$ compared to SS diet. Egg weight, feed intake and body weight of birds were not affect by Se source in all groups (Table 2).

Table 2. Effect of different selenium sources on productive performance parameters of laying hens from 30 to 42 weeks of age.

\begin{tabular}{lcccccc}
\hline Treatments & $\begin{array}{c}\text { Live body } \\
\text { weight change }(\mathbf{g})\end{array}$ & $\begin{array}{c}\text { Feed intake } \\
(\mathbf{g} / \mathbf{d})\end{array}$ & $\begin{array}{c}\text { Feed conversion } \\
(\mathbf{g} \text { feed/g egg mass) }\end{array}$ & $\begin{array}{c}\text { Egg production } \\
(\mathbf{\%})\end{array}$ & $\begin{array}{c}\text { Egg weight } \\
(\mathbf{g})\end{array}$ & $\begin{array}{c}\text { Egg mass } \\
(\mathbf{g} / \mathbf{d})\end{array}$ \\
\hline Control & $266 \pm 6.01$ & $117.55 \pm 1.50$ & $3.55^{\mathrm{a}} \pm 0.06$ & $60.05^{\mathrm{c}} \pm 0.59$ & $47.50 \pm 0.12$ & $33.66^{\mathrm{c}} \pm 0.33$ \\
SS & $267 \pm 6.10$ & $118.75 \pm 0.95$ & $3.45^{\mathrm{a}} \pm 0.07$ & $61.21^{\mathrm{c}} \pm 0.86$ & $47.85 \pm 0.11$ & $33.99^{\mathrm{c}} \pm 0.35$ \\
Nano-Se & $280 \pm 7.05$ & $120.35 \pm 1.09$ & $3.31^{\mathrm{b}} \pm 0.04$ & $73.21^{\mathrm{a}} \pm 0.98$ & $48.01 \pm 0.15$ & $36.90^{\mathrm{a}} \pm 0.35$ \\
Sel-Plex & $274 \pm 5.12$ & $119.40 \pm 0.98$ & $3.43^{\mathrm{b}} \pm 0.04$ & $70.08^{\mathrm{b}} \pm 1.02$ & $47.99 \pm 0.20$ & $35.89^{\mathrm{a}} \pm 0.34$ \\
Significant & $\mathrm{NS}$ & $\mathrm{NS}$ & $* *$ & $* *$ & $\mathrm{NS}$ & $* *$ \\
\hline
\end{tabular}
a-c: Means in the same column followed by different letters are significantly different. $\mathrm{NS}=$ not significant and $* *(\mathrm{P} \leq 0.01)$. $\mathrm{SS}=$ sodium selenite.

The present results agree with the report of Nadia Radwan et al. (2015) who indicated that increasing the level of Se supplementation does not affect feed intake of hens fed various concentrations ( 0 to $0.25 \mathrm{ppm}$ ) of Nano-Se. On the other hand, addition Nano-Se by 0.30 ppm significantly enhanced FC (Zhou and Wang, 2011; Cai et al., 2012). The percentage of egg production was improved by addition organic selenium in layer feed (Gjorgovska et al., 2012; Nadia Radwan et al., (2015)). Also, Attia et al. (2010) observed that egg weight and egg mass significantly increased and feed conversion ratio improved by selenium supplementation when compared with hens fed the control diet. Nevertheless, Se source has not affected in the egg production percentage (Leeson et al., 2008; Reis et al., 2009; Attia et al., 2010).

Egg quality: The both external and internal egg quality were not affected by Se source, except of Yolk color of egg, shell thickness and percentage which were significantly affected by Se source of hens exposed to high ambient temperature (Table 3). Addition Selenium by $0.30 \mathrm{ppm}$ (Nano-Se or Sel-Plex) significantly enhanced Yolk color, thickness and percentage of shell.
The highest value of Yolk color, thickness and percentage of shell were recorded in layer hens fed diets with $0.30 \mathrm{ppm}$ of Nano-Se flowed by hens fed SelPlex compared with control. While, Haugh unit, egg yolk and egg shape index were insignificantly increased by Se source. The highest value was recorded for 0.30 ppm of Nano-Se flowed by Sel-Plex group as compared with control diet. The addition of Nano-Se and Sel-Plex to control diet ameliorated the adverse effect of high ambient temperature. Nadia Radwan et al. (2015) and Attia et al. (2010) were found that addition inorganic (SS) or organic selenium in birds diets, also had no significantly affected on all traits of both egg quality, showing that selenium content of the basal diet was enough to support egg production of good quality. On the other hand, Gjorgovska et al. (2012) indicated that Se sources not affected in ratio of albumin, yolk and shell egg. As well as, Paton et al. (2000) reported that addition $0.3 \mathrm{ppm}$ selenium (inorganic or organic) had insignificant on Haugh unit when compared with control group. Conversely, Gajcevic et al. (2009) indicated that hens fed a diet with organic selenium had higher Haugh unit record than eggs in control group. 
Table 3. Effect of different selenium sources on some egg quality (Means \pm S.E).

\begin{tabular}{lcccccccc}
\hline Treatment & $\begin{array}{c}\text { Yolk } \\
\text { color }\end{array}$ & $\begin{array}{c}\text { Shell thickness } \\
(\mathbf{m m})\end{array}$ & $\begin{array}{c}\text { Haugh } \\
\text { unit }\end{array}$ & $\begin{array}{c}\text { Egg yolk } \\
\text { index\% }\end{array}$ & $\begin{array}{c}\text { Egg shell } \\
\text { \%o }\end{array}$ & $\begin{array}{c}\text { Egg yolk } \\
\text { \% }\end{array}$ & $\begin{array}{c}\text { Egg } \\
\text { albumin \% }\end{array}$ & $\begin{array}{c}\text { Egg shape } \\
\text { index }\end{array}$ \\
\hline Control & $5.5^{\mathrm{b}} \pm 0.21$ & $0.370^{\mathrm{b}} \pm 0.01$ & $78.20 \pm 0.81$ & $44.55 \pm 0.25$ & $11.41^{\mathrm{c}} \pm 0.28$ & $31.00 \pm 0.31$ & $55.90 \pm 0.60$ & $75.36 \pm 0.86$ \\
SS & $5.3^{\mathrm{b}} \pm 0.30$ & $0.361^{\mathrm{c}} \pm 0.01$ & $78.14 \pm 1.15$ & $44.45 \pm 0.30$ & $11.36^{\mathrm{c}} \pm 0.35$ & $31.00 \pm 0.25$ & $56.30 \pm 0.44$ & $75.21 \pm 1.00$ \\
Nano-Se & $5.8^{\mathrm{a}} \pm 0.08$ & $0.382^{\mathrm{a}} \pm 0.01$ & $78.70 \pm 0.86$ & $45.00 \pm 0.46$ & $11.75^{\mathrm{b}} \pm 0.25$ & $31.00 \pm 0.22$ & $55.80 \pm 0.48$ & $75.55 \pm 0.76$ \\
Sel-Plex & $5.4^{\mathrm{b}} \pm 0.36$ & $0.380^{\mathrm{a}} \pm 0.01$ & $78.60 \pm 0.16$ & $44.80 \pm 0.26$ & $11.85^{\mathrm{b}} \pm 0.38$ & $31.20 \pm 0.18$ & $56.70 \pm 0.70$ & $75.78 \pm 0.76$ \\
Significant & $*$ & $*$ & NS & NS & $*$ & NS & NS & NS \\
\hline
\end{tabular}

a-c: Means in the same column followed by different letters are significantly different. $\mathrm{NS}=$ not significant and $*(\mathrm{P} \leq 0.05)$.

$\mathrm{SS}=$ sodium selenite.

Biochemical parameters: The effect of different dietary Se sources in the liver functions (Table 4), Nano-Se and Sel-Plex supplementation caused a significant reduction in plasma total lipid. The greatest reduction was observed when addition $0.3 \mathrm{ppm}$ of Nano-Se to diet was insignificant effect as compared to $0.30 \mathrm{ppm}$ Sel-Plex. The reason of this reduction may be due to vital role of $\mathrm{Se}$ in dominant effects of thyroid
(T3) hormone on fat metabolism (Masukawa et al., 1983). Hypercholesterolemia have been found to be related with Se deficiency was related to improve 3hydroxy-3-methylglutary $\mathrm{CoA}$ reductase the microsomes of liver activity (Nassier et al., 1997). The GSH-Px is activity by selenium which plays a vital role as an antioxidant enzymes may be affective on lowering cholesterol.

Table 4. Effect of different selenium sources on some constituents of blood.

\begin{tabular}{lcccccc}
\hline Treatment & $\begin{array}{c}\text { Total lipids } \\
(\mathbf{g} / \mathbf{d l})\end{array}$ & $\begin{array}{c}\text { Total protein } \\
(\mathbf{g} / \mathbf{d l})\end{array}$ & $\begin{array}{c}\text { Albumin } \\
(\mathbf{g} / \mathbf{d})\end{array}$ & $\begin{array}{c}\text { Globulin } \\
(\mathbf{g} / \mathbf{d})\end{array}$ & $\begin{array}{c}\text { A/g } \\
\text { Ratio }\end{array}$ & $\begin{array}{c}\text { Serum AST } \\
(\text { IUU/L) }\end{array}$ \\
\hline Control & $17.0^{\mathrm{a}} \pm 1.17$ & $5.71^{\mathrm{c}} \pm 0.27$ & $2.40 \pm 0.03$ & $3.31^{\mathrm{c}} \pm 0.09$ & $0.72^{\mathrm{a}} \pm 0.01$ & $120.9^{\mathrm{a}} \pm 0.87$ \\
SS & $16.1^{\mathrm{a}} \pm 0.29$ & $6.28^{\mathrm{b}} \pm 0.16$ & $2.69 \pm 0.04$ & $3.59^{\mathrm{b}} \pm 0.28$ & $0.74^{\mathrm{a}} \pm 0.11$ & $129.5^{\mathrm{a}} \pm 0.34$ \\
Nano-Se & $13.22^{\mathrm{b}} \pm 0.33$ & $7.19^{\mathrm{a}} \pm 0.21$ & $2.2 \pm 0.07$ & $4.99^{\mathrm{a}} \pm 0.33$ & $0.44^{\mathrm{c}} \pm 0.10$ & $110.3^{\mathrm{b}} \pm 0.91$ \\
Sel-Plex & $14.63^{\mathrm{b}} \pm 0.54$ & $5.99^{\mathrm{bc}} \pm 0.11$ & $2.38 \pm 0.09$ & $3.61^{\mathrm{b}} \pm 0.32$ & $0.65^{\mathrm{b}} \pm 0.10$ & $113.4^{\mathrm{b}} \pm 0.49$ \\
Significant & $* *$ & $* *$ & NS & $* *$ & $* *$ & $*$ \\
\hline
\end{tabular}

a-c: Means in the same column followed by different letters are significantly different. $\mathrm{NS}=$ not significant, ${ }^{*}(\mathrm{P} \leq 0.05)$ and $* *(\mathrm{P} \leq 0.01)$. SS= sodium selenite.

The effects of dietary Nano-Se on blood constituents are presented in Table 4. Total protein was increased by dietary all types of Se source, Nano-Se recorded the highest total protein value followed by SelPlex. The same trend was obtained with $\mathrm{A} / \mathrm{g}$ ratio, the highest value of globulin was obtained by using $0.3 \mathrm{ppm}$ of Nano-Se while, there were insignificant differences between albumin values recorded by different groups. It seem that Nano-Se and Sel-Plex has also been proven beneficial in alleviating the side effects of hot climate.

The Se source had significantly affect in AST enzyme. The birds fed either Nano-Se or Sel-Plex recorded lower values of AST enzyme compared with control group. On the other hand, the birds fed SS recorded the highest value as compared with all groups. The results are disagreement with that reported by Yang et al. (2012) who observed that selenium (organic or inorganic ) didn't affected in liver enzymes. Moreover,
Mohapatra et al. (2014) found also liver enzymes were insignificantly between sodium selenite $(0.3 \mathrm{ppm})$ and Nano-Se $(0.15,0.30$ and $0.60 \mathrm{ppm})$ treated.

Results are presented in the Table 5. Under hot temperature, addition Nano-Se, Sel-Plex and SS had a positive $(\mathrm{P} \leq 0.05)$ effect on spermatozoa count and motility. The spermatozoa counts of experimental groups with supplementary Nano-Se and Sel-Plex were similar and substantially higher than the control group followed by SS group. Semen samples from basal chickens contained a significant increased percentage of dead spermatozoa than any of the other groups. Inclusion of Se source reduced the percentage of dead spermatozoa under hot climate conditions and had no effect on ejaculate volume compared with control (Table 5). Insignificant affect of dietary treatment on seminal plasma $\mathrm{Ca}^{++}$concentration was detected.

Table 5. Mean ( \pm SE) volume of semen, concentration, motility and percentage of dead spermatazoa in cockerels fed on diets with or without dietary supplementary SS, Nano-Se and Sel-Plex.

\begin{tabular}{lccccc}
\hline Treatments & $\begin{array}{c}\text { Semen } \\
\text { Volume }(\mathbf{m l})\end{array}$ & $\begin{array}{c}\text { Spermatazoa } \\
\text { Total }(\times \mathbf{1 0} / \mathbf{m l})\end{array}$ & $\begin{array}{c}\text { Motility } \\
(\mathbf{s c o r e})\end{array}$ & $\begin{array}{c}\text { Dead } \\
(\mathbf{\%})\end{array}$ & $\begin{array}{c}\text { Seminal plasma } \\
\mathbf{C a}++(\mathbf{m g} / \mathbf{1 0 0 m l})\end{array}$ \\
\hline Control & $0.31 \pm 0.01$ & $1.87^{\mathrm{c}} \pm 0.17$ & $4.10^{\mathrm{b}} \pm 0.18$ & $16.17^{\mathrm{a}} \pm 0.68$ & $9.65 \pm 0.4$ \\
SS & $0.32 \pm 0.01$ & $2.84^{\mathrm{b}} \pm 0.18$ & $4.35^{\mathrm{b}} \pm 0.17$ & $8.63^{\mathrm{b}} \pm 0.81$ & $9.68 \pm 0.4$ \\
Nano-Se & $0.31 \pm 0.01$ & $2.95^{\mathrm{a}} \pm 0.17$ & $4.98^{\mathrm{a}} \pm 0.19$ & $6.01^{\mathrm{b}} \pm 0.74$ & $9.69 \pm 0.3$ \\
Sel-Plex & $0.32 \pm 0.01$ & $2.91^{\mathrm{a}} \pm 0.17$ & $4.97^{\mathrm{a}} \pm 0.18$ & $6.82^{\mathrm{b}} \pm 0.79$ & $9.72 \pm 0.3$ \\
Significant & $\mathrm{NS}$ & $*_{*}$ & $* *$ & $*^{*}$ & $\mathrm{NS}$ \\
\hline
\end{tabular}

a-c: Means in the same column followed by different letters are significantly different. $\mathrm{NS}=$ not significant, $*(\mathrm{P} \leq 0.05)$ and $* *(P \leq 0.01)$. SS= sodium selenite.

Dietary supplementation ameliorated the sids effects of hot climate on lipids peroxidation and also, antioxidative properties in birds semen (Figure). Dietary supplementation with Se source decreased TBARS values (Figure, A1,2), of antioxidants reduced the
TBARS in seminal and blood plasma, respectively . (Figure, B1, 2). Supplementary dietary Se source showed a positive effect on antioxidant properties as measured by TBARS and GSH-Px activity in seminal and blood plasma, respectively. Under hot climate 
conditions, the inclusion of $0.3 \mathrm{ppm}$ Nano- Se or 0.3 ppm Sel-Plex, markedly enhanced the plasma of semen GSH-Px activity by more than two-fold as compared

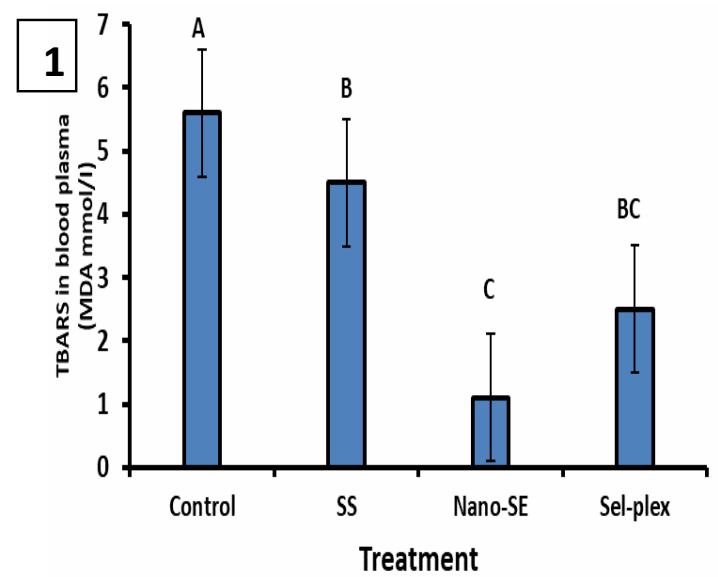

with controls in seminal and blood plasma, respectively (Figure, B1,2).

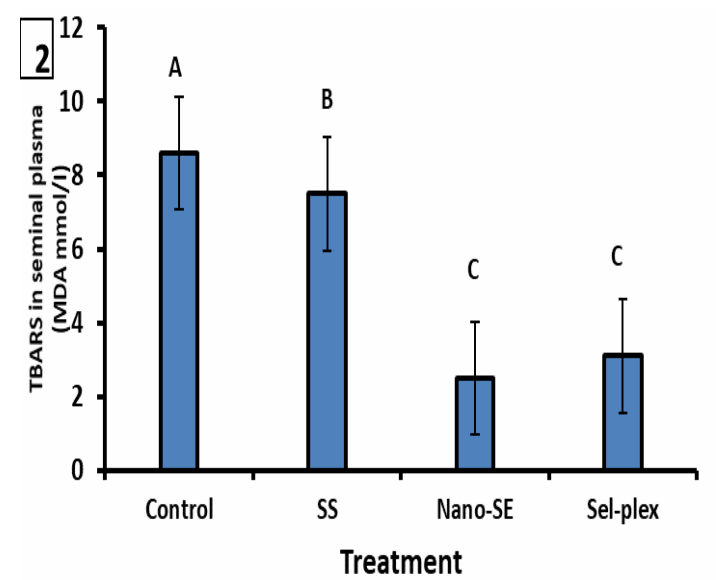

Fig. A. Effect of different sources of dietary Se on blood MDA (1) and seminal MDA (2) contents in chickens exposed to high ambient temperatures (means $\pm \mathrm{SE}$ ).
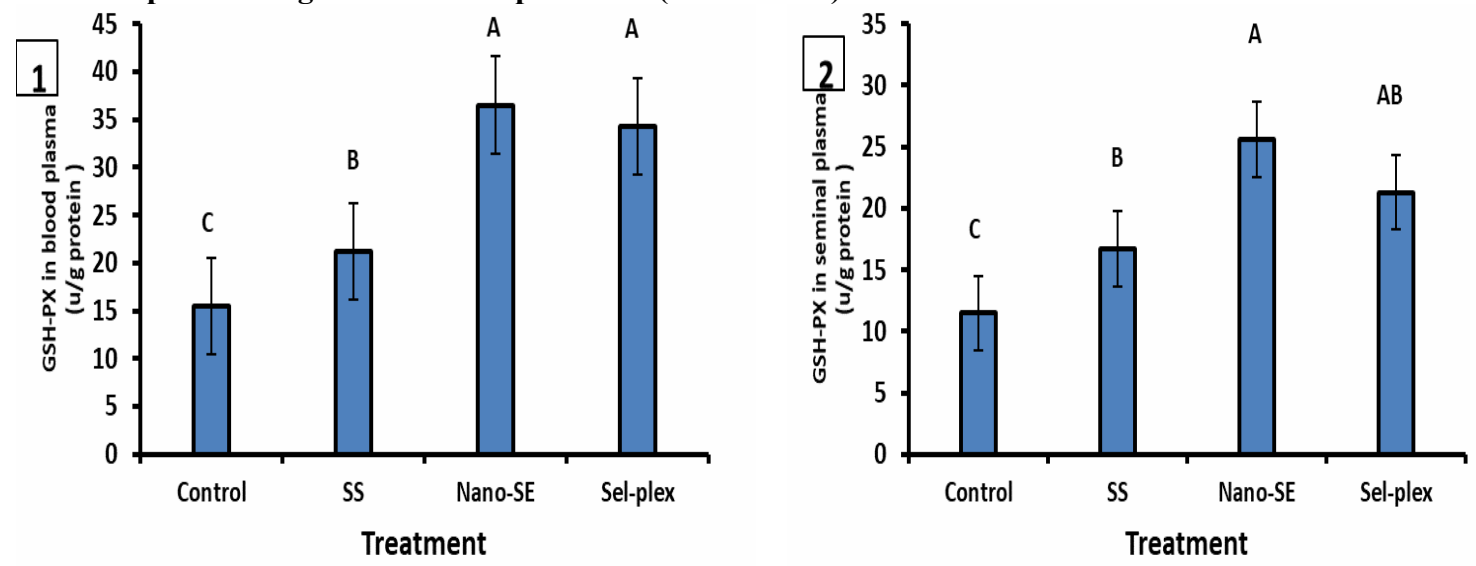

Fig. B. Effect of different sources of dietary Se on blood GSH-PX (1) and seminal GSH-PX (2) contents in chickens exposed to high ambient temperatures (means $\pm \mathrm{SE}$ ).

Heat stress, (summer Egypt) high ambient temperature, affects semen quality characteristics in chickens and subsequently the flock fertility (McDaniel et al., 1995 \& 1996; Kalamah, 2001). Moreover, it was documented that stress could improve lipids peroxidation in both the plasma of semen and the spermatozoa membranes, the results in reduction of the spermatozoa count (Surai et al., 1998a \& b; Eid et al., 2006). Results of during study show the positive effects of Nano-Se and organic Se supplementation on semen quality characteristic, inclusive spermatozoa count, motility and the percentage of dead spermatozoa under high ambient temperature (Table5). Recently results are agreement with other results which indicated that organic Se (Ebeid, 2009) led to enhance semen quality in cockerels by increasing concentrations of spermatozoa and cell viability under stress conditions. Several studies have also reported improvements in spermatozoa quantity and quality with supplemental Se in poultry (Hanafy et al., 2009; Lin et al., 2005) and in mammals (Yousef, 2010; Yue et al., 2010). Se supplementation plays a vital role in improving the semen quality in cockerels, especially under stressful conditions. Mammalian (Kelso et al., 1997) and avian (Surai et al., 1997 \& 1998b) spermatozoa are characterized by highly increase concentrations of PUFA in the phospholipids that are oversensitive to peroxidative damages, and are considered to be a cause of male sub fertility (Aitken, 1994). Consequently, an effective antioxidant system such as (GPX) is required to keep spermatozoa membranes against ROS and peroxidative damages (Eid et al., 2006; Ebeid, 2009; Ebeid, 2012).

The functionsof selenium in the cytoplasm is destroy peroxides (Surai, 2002) suggesting synergism between both in the antioxidative system. In addition, Se is necessary for the development of spermatozoa and spermatozoa production, via their effects on increasing testosterone concentrations (Kaur and Bansal, 2004). Collectively, these studies clearly indicate that addition natural antioxidant is essential for normal spermatozoa development, integrity and protection, and are likely to be involved in improving semen quality traits under HS conditions. Males supplemented with different $\mathrm{Se}$ 
source were characterized by better resistance to hot climate conditions and this was reflected by best motility and better concentration (Table5). Furthermore, on the biochemical rate, the defensive effect of Nano-Se and Sel-Plex were related to a decrease in lipids peroxidation in blood and semen (Figure A1,2). It is well know that lipids are one of the vital component of semen, participate to cellmembrane structure, metabolism and the capability to capacitate and fertility of oocytes (Surai, 2002). The highly concentrations of PUFA within the lipids fraction require the presence of

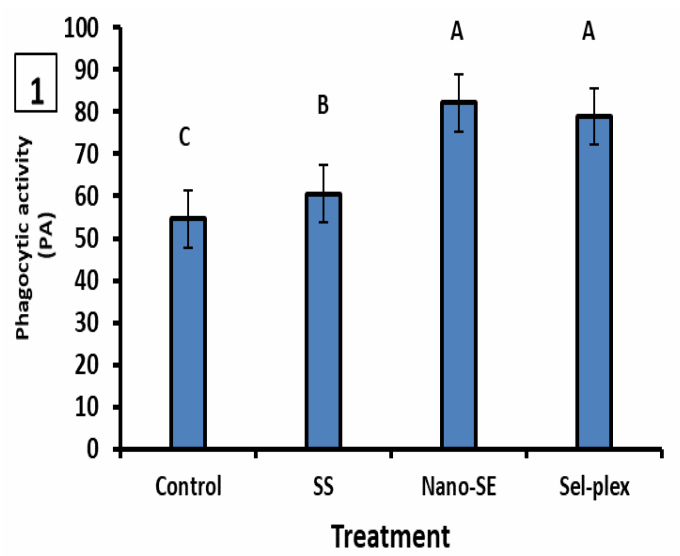

an effective antioxidant system enzymes to protect against per oxidative damages, and associated spermatozoa dysfunction and male infertility (Aitken, 1994; Surai et al., 1997). Therefore, it could be expected that decreasing the concentration of TBARS in seminal plasma would be associated with enhanced spermatozoa motility and concentration under stressors conditions. In Figure A, the TBARS as an index of lipids peroxidation, the $0.3 \mathrm{mg}$ of Nano-Se and organic Se provided the greatest protective effect against lipid peroxidation in plasma of semen.

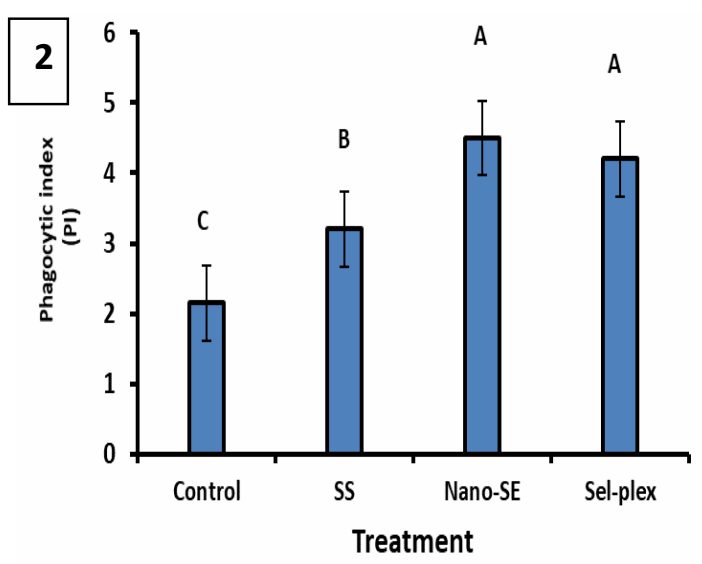

Fig. C. Effect of different sources of dietary Se on Phagocytic activity and Phagocytic index (2) contents in chickens exposed to high ambient temperatures (means $\pm \mathrm{SE}$ ).

Lipids peroxides was detoxification by GSH-Px enzyme involved selenium, which plays a great role in that which can appear in birds spermatozoa (Froman and Thurston, 1981). In birds and spermatozoa, nearly $60 \%$ and $40 \%$ of the Se dependent form of active GSHPx in semen spermatozoa was observed in plasma of semen (Surai et al., 1998b). Additionally, it was demonstrated that the inclusion of Nano-Se and SelPlex $(0.3 \mathrm{mg} / \mathrm{kg})$ in the male diet significantly increased Se-dependent GSH-Px activity, which is correlating with better protection against lipid peroxidation in semen under all climate conditions (Surai et al., 1998a) specially ,under heat stress conditions (Ebeid, 2009).

The effects of dietary different sources of Se on Phagocytic activity (PA) and Phagocytic index (PI) the immune response are shown in Figure C1, 2. Dietary $0.3 \mathrm{ppm}$ Sel-Plex or Nano-Se had positive significant effect on PA and PI of chickens $(\mathrm{P}<0.05)$ under high ambient temperature. Under hot climate conditions, the PA and PI were greater in dietary $0.3 \mathrm{ppm}$ Sel-Plex or Nano-Se compared as control and SS $(\mathrm{P}<0.05)$.

As presented in Fig. C1,2, dietary Se supplementation had a immunostimulating effect (PA and PI) of birds subjected to heat stress and our results support with regared to the antioxidative parameters were discussed above. The results from the current trial are in agreement with several studies (Niu et al., 2009; Liao et al., 2012; Habibian et al., 2014) which indicated that addition organic Se (sel plex) improved titer of antibody when chickens were exposed to stress conditions. Virtually, there is an evidence that Se addition led to give more health advantages on the immunity response and reduced inflammation (Rayman,
2004). Rooke et al. (2004) indicated that Se is involved in many of immune functions, at all levels, like reduction of glucocorticoids (indicator for immunity disorder), minimizing levels and duration of inflammatory infections, arrangement the function of $\mathrm{T}$ lymphocytes cell and $\mathrm{T}$ killer cells and activation of IL-2. Recently, Zamani Moghaddam et al. (2017) observed an improvement in total anti-sheep red blood cell (SRBC) in birds fed on a diet including with Nano-Se at $0.3 \mathrm{mg} / \mathrm{kg}$ compared to those fed on a diet supplemented with SS

\section{CONCLUSION}

Based on the data presented on this study and taking into account the antioxidant interactions, it could be assumed that dietary $0.3 \mathrm{ppm}$ organic Se or Nano-Se might be involved in enhancing productive performance, egg quality, semen quality, antioxidative properties and immunity in hens reared under hot climate conditions.

\section{REFERENCES}

Agriculture Ministry Decree, (1996). The standard properties for ingredients, feed additives and feed manufactured for animal and poultry. El-Wakaee El- Masria, No. 192 (1997) pp. 95 Almeria Press Cairo, Egypt.

Aitken, R.J. (1994) Free radical theory of male in fertility. Reproduction and Fertility Development, 6: 19-24.

Aitken, R.J.; J.S. Clarkson and S. Fishel (1989). Generation of reactive oxygen species, lipid peroxidation, and human sperm function. Biology of Reproduction, 40:183-197. 
Arthur, J.R (2000). The glutathione peroxidases. Cell Mol Life Sci 57:1825-1835.

Arthur, J.R.; G.J. Beckett and J.H. Mitchell (1999). The interactions between selenium and iodine deficiencies in man and animals. Nutr. Res. Rev.,12: 55-73.

Attia, Y.A.; A.A. Abdalah; H.S. Zeweil; F. Bovera; A.A. Tag El- Din and M.A. Araft (2010). Effect of inorganic or organic selenium supplementation on productive performance, egg quality and some physiological traits of dual-purpose breeding hens. Czech J. Anim. Sci., 55: 505-519.

Cai, S.J.; C.X. Wu; L. M. Gong; T. Song; H. Wu and L.Y. Zhang (2012). Effects of nano-selenium on performance, meat quality, immune function, oxidation resistance and tissue selenium content in broilers. Poult. Sci., 91: 2532-2539.

Doucha J.; K. Livansk; V. Kotrbacek and V. Zachleder (2009). Production of Chlorella biomass enriched by selenium and its use in animal nutrition:a review. Applied Microbiology and Biotechnology, 83, 0011008.

Duncan, D.B.(1955).Multiple range and multiple FTest. Biomet., 11:1-42.

Ebeid T.A. (2012).Vitamin E and organic selenium enhances the antioxidative status and quality of chicken cockerel semen under high ambient temperature. British Poultry Science.Vol 5.708-714.

Ebeid, T. (2009). Organic selenium enhances the antioxidative status and quality of cockerel semen under high ambient temperature. British Poultry Science, 50: 641-647.

Ebeid, T.A.; H.S. Zeweil; M.M. Basyony; W.M. Dosoky and H. Badry (2013). Fortification of rabbit diets with vitamin $\mathrm{E}$ or selenium affects growth performance, lipid peroxidation, oxidative status and immune response in growing rabbits. Livestock Science 155: 323-331.

Eid, y.; T.A. Ebeid and H. Younis (2006). Vitamin E supplementation reduces dexamethasoneinduced oxidative stress in chicken semen. British Poultry Science,47: 350-356.

Eisen, E.J.; B.B. Bohren and M. Mckean (1962). The Haugh Unit as a measure of egg albumin quality. Poult. Sci., 41: 1461.

El-Deep, M.H.; D. Ijiri1; T.A. Ebeid and A. Ohtsuka (2016). Effects of dietary nano-selenium supplementation on growth performance, antioxidative status, and immunity in broiler chickens under thermoneutral and high ambient temperature conditions. Journal of Poultry Science. Vol. 53 (2) No. 4 pp. 274-283.

Eszenyi , P.; A. Sztrik; B. Babka and J. Prokisch (2011). Elemental, nano-sized $(100-500 \mathrm{~nm})$ selenium production by probiotic lactic acid bacteria. Int $\mathrm{J}$ Biosci Biochem Bioinformatics $1: 148-152$.

Froman, D.P. and R.J. Thurston (1981) .Chicken and turkey spermatozoal superoxide dismutase: a comparative study. Biology of Reproduction, 24: 193-200.
Gajcevic, Z., G. ; Kralik, E. Has-Schon and V. Pavic (2009). Effects of organic selenium supplemented to layer diet on table egg freshness and selenium content. Ital. J. Anim. Sci., 8: 189-199.

Gindler, E.M. and J.D. King (1972). Rapid colormetric determination of calcium in biological fluids. Am. J. Clin. Path., 58: 376-382.

Gjorgovska, N., F.; Kiril, L. Vesna and K. Tosho (2012). The effect of different levels of selenium in feed on egg production, egg quality and selenium content in yolk. Lucrariatiinpifice-Seria Zootehnie, 57: 270-274.

Habibian, M.; S. Ghazi; M.M. Moeini and A. Abdolmohammadi (2014). Effects of dietary selenium and vitamin $\mathrm{E}$ on immune response and biological blood parameters of broilers reared under thermoneutral or heat stress conditions. Int J Biometeorol (DOI 10.1007).

Hanafy, M.M.; A.M.H. El-Sheikh and E.A. Abdalla (2009). The effect of organic selenium supplementation on productive and physiological performance in a local strain of chicken. 1-The effect of organic selenium $\left(\right.$ Sel-Plex $\left.{ }^{\mathrm{TM}}\right)$ on productive, reproductive and physiological traits of bandarah local strain. Egyptian Poultry Science, 29: 1061-1084.

Haugh, R.R.,(1937).The Haugh unit for measuring egg quality.United States. Egg Poult. Magazine, 43: $552-555$.

Jia, X.; N. Li and, J. Chen (2005). A subchronic toxicity study of elemental Nano-Se in Sprague-Dawley rats. Life Sci. 76, 1989-2003.

Kalamah, M.A. (2001). Some physiological responses to heat stress in bronze turkey toms. Egyptian Poultry Science, 21: 833-852.

Kaur, P. and M.P. Bansal (2004). Effect of experimental oxidative stress on steriodogenesis and DNA damage in mouse testis. Journal of Biomedical Science, 11:391- 397.

Kelso, K.A.; A. Redpath ; R.C. Noble and B.K. Speake (1997).Lipid and antioxidant changes in spermatozoa and seminal plasma throughout the reproductive period of bulls. Journal of Reproduction and Fertility, 109:1-6.

Koracevic, D.; G. Koracevic; V. Djordjevic; S. Andrejevic and V.Cosic (2001). Method for the measurement of antioxidant activity in human fluids.Journal of Clinical Pathology,54:356-361.

Kotaiah, T. and S.C. Mohapatra (1974). Measurement of albumin quality.India Poult.Ganzette.,59: 121.

Lake, P.E and J.M. Stewart (1978). Artificial insemination in poultry, in: Ministry of Agriculture, Fisheries and Food Bulletin No. 213, (London, H.M. Stationery Office).

Leeson, S.; H. Namkung; L. Caston; S. Durosoy and P. Schlegel (2008). Comparison of selenium levels and sources and dietary fat quality in diets for broiler breeders and layer hens. Poult. Sci., 87: 2605-2612.

Liao, X.; L. Lu; S. Li; S. Liu; L. Zhang; G. Wang; A. $\mathrm{Li}$ and X. Luo (2012). Effects of Selenium Source and Level on Growth Performance, Tissue Selenium Concentrations, Antioxidation, and Immune Functions of Heat-Stressed Broilers. Biol Trace Elem Res 150:158-165. 
Lin, Y.F.; S.J. Chang; J.R. Yang; Y.P. Lee and A.L. Hsu (2005) . Effects of supplemental vitamin E during the mature period on the reproduction performance of Taiwan native chicken cockerels. British Poultry Science, 46: 366-373.

Lopes, S.; A. Jurisicova; J.G. Sun and R.F. Casper (1998). Reactive oxygen species: potential cause for DNA fragmentation in human spermatozoa. Human Reproduction, 13: 896-900.

Masukawa, T.; J. Goto and H. Iwata (1983). Impaired metabolism of arachidonate in selenium deficient animals. Experientia, 39: 405-406.

McDaniel, C.D.; R.K. Bramwell and J.R. Howarth (1996) The male contribution to broiler breeder heat induced infertility as determined by spermegg penetration and sperm storage within the hen's oviduct. Poultry Science, 75: 1546-1554.

McDaniel, C.D.; R.K. Bramwell; J.L. Wilson and B. Howarth (1995). Fertility of male and female broiler breeders following exposure to an elevated environmental temperature. Poultry Science, 74: 1029-1038.

Melesse, A.; S. Maak; R. Schmidt and G. von Lengerken (2011). Effect of long-term heat stress on some performance traits and plasma enzyme activities in naked-neck chickens and their F1 crosses with commercial layer breeds. Livest Sci 141:227- 231.

Melrose, D.R and J.A. Laing (1970). Fertility and Infertility in the Domestic Animals, 2ndedn (London, Bailliere Tindall).

Mohapatra, P.; R.K. Swain; S.K. Mishra; T. Behera; P.Swain; S.S. Mishra; N.C. Behura; S.C. Sabat; K. Sethy; K. Dhama and P. Jayasankar (2014). Effects of dietary nano-selenium on tissue selenium deposition, antioxidant status and immune functions in layer chicks.Int.J. Pharmacol., 10:160-167.

Nadia L. Radwan; T.A. Salah Eldin; A.A. EL-Zaiat and Mona A.S.A. Mostafa (2015). Effect of Dietary Nano-Selenium Supplementation on Selenium Content and Oxidative Stability in Table Eggs and Productive Performance of Laying Hens. International Journal of Poultry Science 14(3):161-176.

Nassier, F.; C. Moundras; D. Bayle; C. Serougne; E.Gueux; E. Rock; Y. Rayssiguier and A. Mazur (1997). Effect of selenium deficiency on hepatic lipid and lipoprotein metabolism in the rat. Br. J. Nutr., 78: 493-500.

Niu, Z.; F. Liu; Q. Yan and L. Li (2009). Effects of different levels of selenium on growth performance and immunocompetence of broilers under heat stress. Arch. Anim. Nutr. 63:56-65.

Paglia, D.E. and W.N. Valentine (1967). Studies on the quantitative and qualitative characterization of erythrocyte glutathione peroxidase. The Journal of Laboratory and Clinical Medicine, 70:158-69.

N.R.C., 1994. National Research Council. Nutrient Requirements of Poultry. 9th Ed. National Academy of Sciences. Washington, D.C., USA.
Paton, N.D.; A.H. Cantor; A.J. Pescatore and M.J. Ford (2000). Effect of dietary selenium source, level of inclusion and length of storage on internal quality and shell strength of eggs. Poult. Sci., 79: 75.

Preter, F.S. (2000). Organic selenium: benefits to animal and humans, a biochemist's view. In: Proceedings of Alltech's 16th symposium. Nottingham University Press, Nottingham, pp: 205-213.

Rayman, M. P. (2004). The use of high-selenium yeast to raise selenium status: How does it measure up? Br. J. Nutr. 92:557-573.

Reis, R.N.; S.L. Vieira; P.C. Nascimento; J.E. Pena; R. Barros and C.A. Torres (2009). Selenium contents of eggs from broiler breeders supplemented with sodium selenite or zinc-l-selenium-methionine. J. Appl. Poult. Res., 18: 151-157.

Richard, M.J.; B. Portal; J. Meo; C. Coudray; A. Hadjian and A Favier (1992). Malondialdehyde kit evaluated for determining plasma and lipoprotein fractions that react with thiobarbituric acid. Clinical Chemistry, 38: 704-709.

Rooke, J. A.; J. J. Robinson and J. R. Arthur (2004). Effects of vitamin $\mathrm{E}$ and selenium on the performance and immune status of ewes and lambs. A Review. J. Agric. Sci., 142: 253-262.

Sauter, E.A.; W.J. Stadelman; V. Harns and B.A. Mclaren (1951). Methods for measuring yolk index. Poult. Sci.,30: 629-630.

Shi, L.G.; W.J. Xun; W.B. Yue; C.X. Zhang; Y.S. Ren; Q. Liu; Q. Wang and L. Shi (2011a). Effect of elemental nano-selenium on feed digestibility, rumen fermentation, and purine derivatives in sheep. Anim Feed Sci Technol 163:136-142.

Shi, L.G.; W.J. Xun; W.B. Yue; C.X. Zhang; Y.S. Ren; L. Shi; Q. Wang; R.J. Yang and F.L. Lei (2011b). Effect of sodium selenite, Se-yeast and nanoelemental selenium on growth performance $\mathrm{Se}$ concentration and antioxidant status in growing male goats. Small Ruminant Res. 96, 49-52.

Siegel, H.S. (1995). Stress, strain and resistance. British Poultry Science, 36: 3-22.

Słowinska, M.; J. Jankowski; G.J. Dietrich; H. Karol; E. Liszewska ; J. Glogowski; K. Kozłowski; K. Sartowska and A. Ciereszko (2011). Effect of organic and inorganic forms of selenium in diets on turkey semen quality. Poultry Science, 90:181-190.

Statistical Packages For The Social Sciences (SPSS $®$ ) (2001). Statistical Software for Windows Version 11.0 Microsoft. Chicago, IL, USA.

Surai, P.F; E. Blesbois; I. Grasseau; T. Ghalah; J.P. Brillard; G. Wishart; S. Cerolini and N.H.C. Sparks (1998b). Fatty acid composition. Glutathione peroxidase and superoxide dismutase activity and total antioxidant activity of avian semen. Comparative Biochemistry and Physiology, 120B: 527-533.

Surai, P.F (2002) . Selenium in poultry nutrition 2. Reproduction, egg and meat quality and practical applications. World's Poultry Science Journal, 58:431-450. 
Surai, P.F.; I. Kostjuk; G. Wishart; A.M.A. Pherson; B.K. Speaek; R.C. Noble; I. Ionov and E. Kutz (1998a) . Effect of vitamin $\mathrm{E}$ and selenium supplementation of cockerel diets on glutathione peroxidase activity and lipid peroxidation susceptibility in sperm, testes, and liver. Biological Trace Elements Research,64:119-132.

Surai, P.F.; E. Kutz; G.J. Wishart; R.C. Noble and B.K. Speake (1997). The relationship between the dietary provision of $\alpha$-tocopherol and the concentration of this vitamin in the semen of chicken: effects on lipid composition and susceptibility to peroxidation. Journal of Reproduction and Fertility, 110: 47-51.

Underwood, E.J. and N.F. Suttle (1999). Selenium. Pages 421-476 in The Mineral Nutrition of Livestock. E.J. Underwood and N.F. Suttle, ed. CABI Publishing, Penicuik, UK.

Wang, H.; J. Zhang and H. Yu (2007). Elemental selenium at nano size possesses lower toxicity without compromising the fundamental effect on selenoenzymes: comparison with seleno-methionine in mice. Free Radic. Biol. Med., 42: 1524-1533.

Wang, Y.B. and B.H. Xu (2008). Effect of different selenium source (sodium selenite and selenium yeast) on broiler chickens. Anim. Feed Sci. Tech.,144: 306-314.

Wang, Z.G.; X.J. Pan; W.Q. Zhang; Z.Q. Peng; R.Q. Zhao and G.H. Zhou (2009). Methionine and selenium yeast supplementation of the maternal diets affects antioxidant activity of breeding eggs. Poult. Sci., 89:931-937.
Yang, Y.R.; F.C. Meng; P. Wang; Y.B. Jiang; Q. Yin; J. Chang; R.Y. Zuo; Q.H. Zheng and J.X. Liu (2012). Effect of organic and inorganic selenium supplementation on growth performance, meat quality and antioxidant property of broilers. Afr. J. Biotechno., 11: 3031-3036.

Yoon, I.; T.M. Werner and J.M. Butler (2007). Effect of source and concentration of selenium on growth performance and selenium retention in broiler chickens. Poult Sci 86:727-730.

Yousef, M.I (2010).Vitamin E modulates reproductive toxicity of pyrethroid lambdacyhalothrinin male rabbits. Food and Chemical Toxicology,48: 1152-1159.

Yue, D.; L. Yan; H. Luo; X. Xu and X. Jin (2010). Effect of vitamin E supplementation on semen quality and the testicular cell membranal and mitochondrial antioxidant abilities in Aohan finewool sheep. Animal Reproduction Science, 118: 217-22.

Zamani Moghaddam, A.; M. Mehraei Hamzekolaei; F. Khajali, and H. Hassanpour (2017). Role of selenium from different sources in prevention of pulmonary arterial hypertension syndrome in broiler chickens. Biological trace element research: 1-7.

Zhou, X. and Y. Wang (2011). Influence of dietary nano elemental selenium on growth performance, tissue selenium distribution, meat quality and glutathione peroxidase activity in Guangxi Yellow chicken. Poult. Sci., 90: 680-686

\section{التأثير المقارن لاستخدام مصادر مختلفة من السيلينيوم فى العليقة على الأداء الإنتاجى و خصائص مضادات

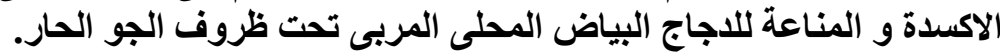

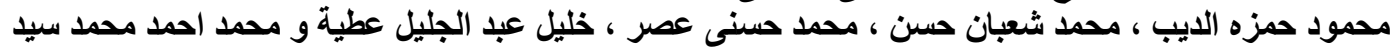

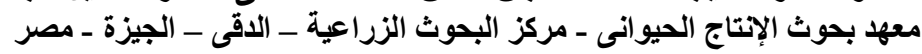

اجريت هذه الدراسة بهدف دراسة تأثنير استخدام مصادر مختلفة من السيلينيوم (صوديوم سيلينيت - خميرة سيلينيوم (سيلبليكس

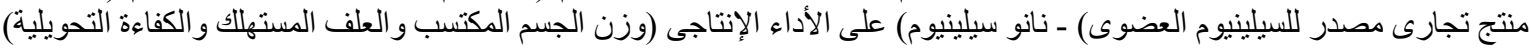

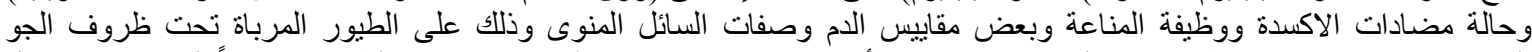

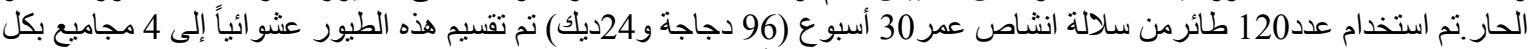

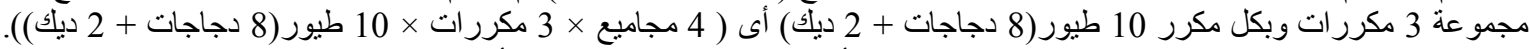

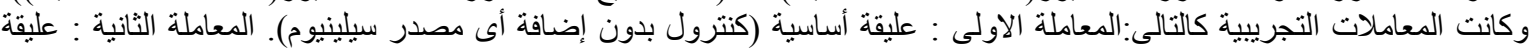

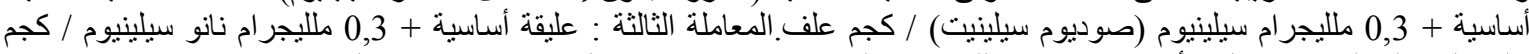

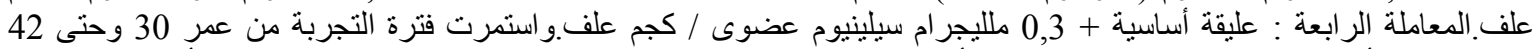

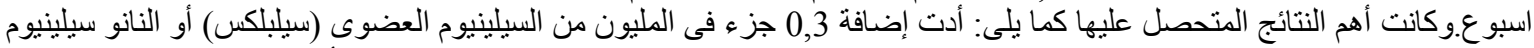

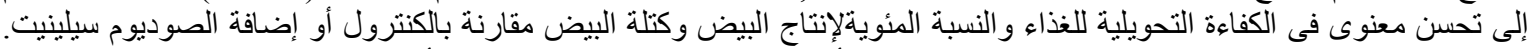

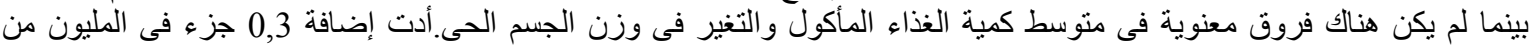

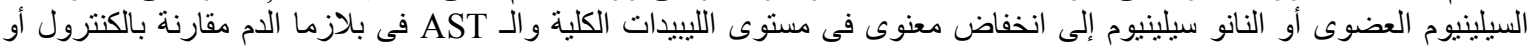

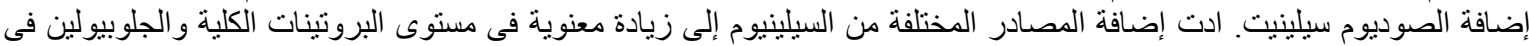

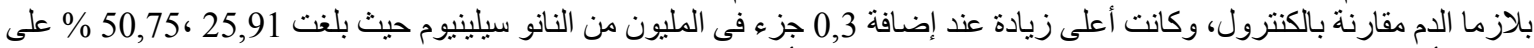

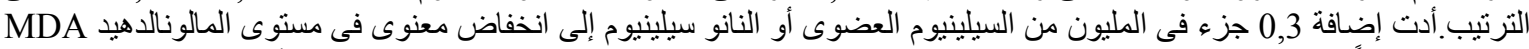

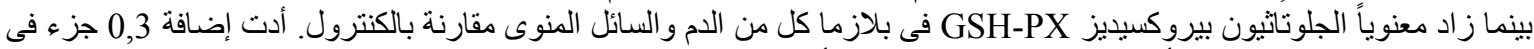

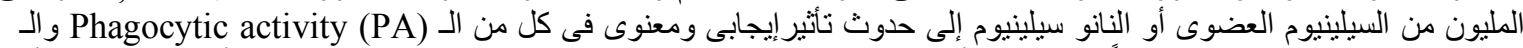

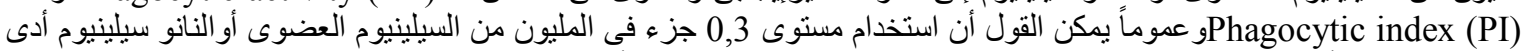
إلى تحسين فى الأداء الإنتاجى وصفات السائل المنوى و الخصائص المضادة للأكسدة ووظيفة المناعة فى الدجاج البياض المرن المربى تحت ظروف الجو الحار. 